\title{
New records of rare and threatened polypores in Finland
}

\author{
TUOMO NIEMELÄ, HEIKKI KOTIRANTA and REIJO PENTTLÏ
}

\begin{abstract}
NIEMELÄ, T., KOTIRANTA, H. \& PENTTILÄ, R. 1992: New records of rare and threatened polypores in Finland. - Karstenia 32:81-94.

The polypores (Basidiomycetes) Antrodia sitchensis (Baxter) Gilb. \& Ryv., Ceriporiopsis balaenae Niemelä and Funalia trogii (Berk.) Bond. \& Singer are reported as new to Finland. Antrodiella parasitica Vampola is tentatively reported from Finland, but its taxonomy has not been sufficiently worked out. The macroscopic and microscopic characters of $A$. sitchensis are described and we propose that the species might find a natural placement in Fomitopsis or Amyloporia, rather than in Antrodia. The generic demarcation between Trametes, Funalia and Coriolopsis is discussed, and the critical difference is reported to lie in the reaction of the skeletal hyphae to Cotton Blue: Trametes is acyanophilous, $F u$ nalia and Coriolopsis cyanophilous. As a gradual transition exists between the characters of Funalia and Coriolopsis, we prefer to join these taxa in a single genus, Funalia. On this basis we accept the species currently known as Trametes trogii Berk. in Funalia. Perenniporia tenuis (Schw.) Ryv. var. pulchella (Schw.) Lowe was considered to be extinct in Finland, but has now been rediscovered. We compare it with Perenniporia tenuis var. tenuis, $P$. medulla-panis (Jacq.: Fr.) Donk, $P$. subacida (Peck) Donk, and P. fulviseda (Bres.) Dhanda. New Finnish records of the following rare species are listed: Antrodiella citrinella Niemelä \& Ryv., Piloporia sajanensis (Parm.) Niemelä, Polyporus pseudobetulinus (Pilát) Thorn et al., Skeletocutis lilacina David \& Keller, and Tyromyces canadensis Overh. ex Lowe. The ecology and distribution of most of the species are discussed.
\end{abstract}

Key words: Antrodia sitchensis, Antrodiella parasitica, Ceriporiopsis balaenae, Finland, Funalia trogii, polypores, taxonomy, threatened fungi, virgin forest

Tuomo Niemelä and Reijo Penttilä, Department of Botany, University of Helsinki, Unioninkatu 44, SF-00170 Helsinki, Finland

Heikki Kotiranta, Water and Environment Research Institute (Nature Conservation), P.OBox 250, SF-00101 Helsinki, Finland

\section{Introduction}

The distributional data on ten polypore taxa published in this paper have accumulated during the recent years. Many records derive from the field work of R.P., carried out to evaluate old forests in eastern Finland. The preparation of this summary was prompted by the wish to make the new data available for a forthcoming manual on the European polypores (by R. Gilbertson and L. Ryvarden). Five of the species listed here are classified as threatened in Finland (Rassi et al. 1992), but the others are also very rare in this country and in Europe as a whole. Many of the species treated here are burdened with taxonomical problems, for instance regarding their proper genera.

\section{Materials and methods}

Most records are based on our own collections, preserved in herb. $\mathrm{H}$ (official abbreviations according to
Holmgren et al. 1990), or in some of the following reference collections: H.K. = Heikki Kotiranta, T.N. = Tuomo Niemelä, R.P. = Reijo Penttilä and P.R. = Pertti Renvall, all linked with or accessible via the Botanical Museum of the University of Helsinki. Some specimens from older collections were obtained from HFR. Reference material was borrowed from several herbaria outside Finland. GB-J.E. means the collections of the Department of Systematic Botany, University of Göteborg, established by Dr. John Eriksson. O-L.R. is the herbarium of Dr. Leif Ryvarden, Biological Institute, University of Oslo.

The microscopical analyses were made by H.K. (in particular Antrodiella parasitica and Funalia trogii) and T.N. (in particular Antrodia sitchensis and Perenniporia tenuis var. pulchella). R.P. collected most of the herbarium data and is responsible for the ecological and most of the distributional notes. 


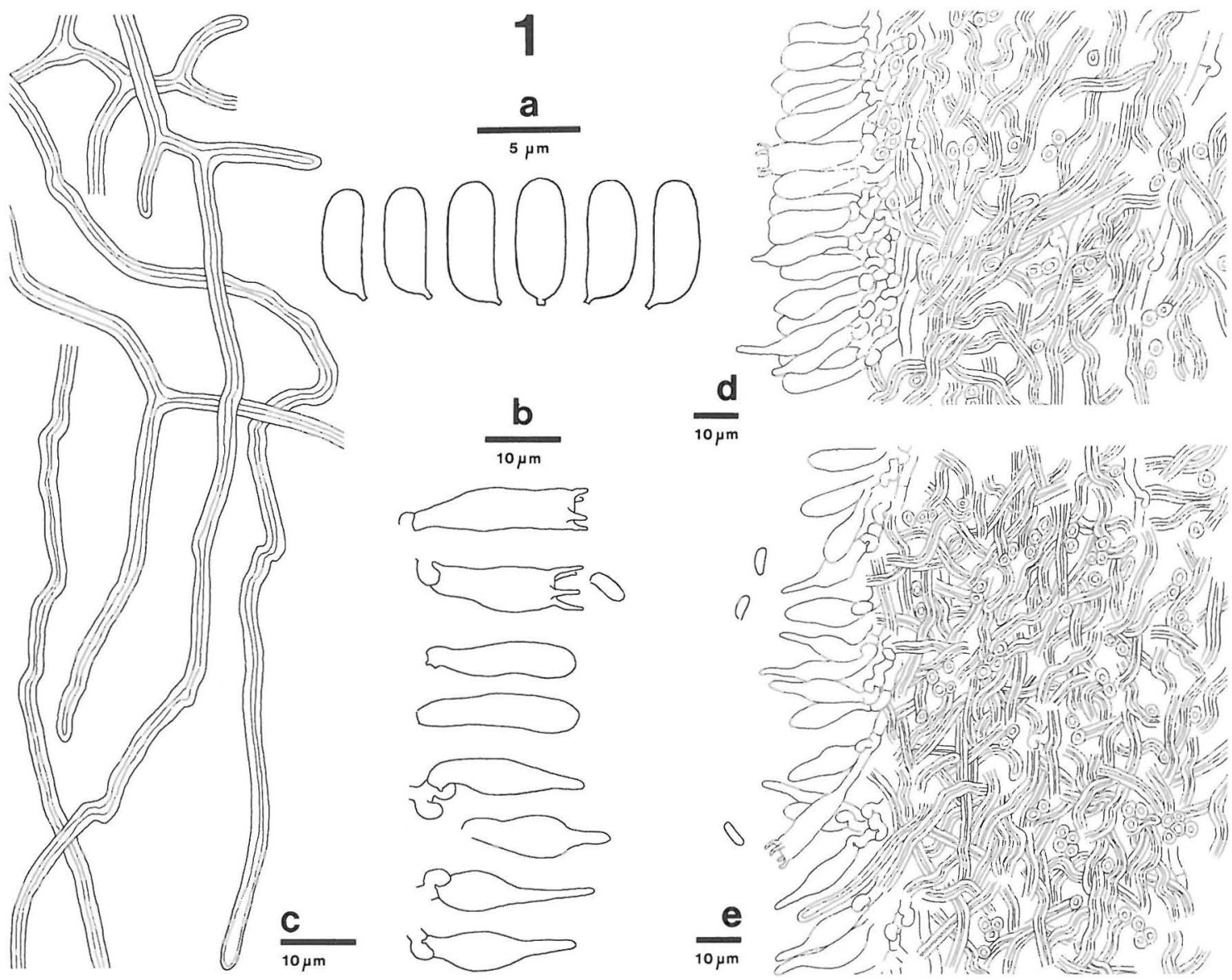

Fig. 1. Anatomical details of Antrodia sitchensis (Baxter) Gilb. \& Ryv., specimen Penttilă 2581 (H). a) spores, b) basidia, basidioles and cystidioles, c) branched skeletal or skeleto-binding hyphae from the subiculum, d) vertical section of a dissepiment showing a well-developed hymenium, e) dissepiment with a degenerating hymenium, abundant cystidioles and a skeletocystidium.

Large pores were counted and their number recorded per centimetre, not per $\mathrm{mm}$ as is usual when describing polypores. This is a more useful and reliable way to express the size of very large pores than giving the inner dimensions of the variable pore cavities. The pores were counted in the direction that gave the greatest number.

A more detailed overview of the research methods can be obtained from the papers of Renvall and Niemelä (1992) and Niemelä and Penttilä (1992).

\section{Antrodia sitchensis (Baxter) Gilb. \& Ryv.}

Finland. Kainuu: Kuhmo, Louhivaara, Pinus sylvestris, Grid 27ํ 70893:6296, 26.IX.1991 Penttilä 2581 (H, R.P., T.N.).
Other specimens examined: Canada. British Columbia: Natural Bridge, down log of Pinus contorta, 3.VIII.1960 Hughes (DAOM 125959). Vancouver Island, Little Qualicum River, fallen Picea sitchensis, 27.VIII.1938 Touzeau \& Mounce (DAOM 8260); same but without date (GB-J.E.). Vancouver Island, Oyster River, at base of $P$. sitchensis, 17.IX.1938 Touzeau (DAOM 8447). Queen Charlotte Islands, Church Creek, butt of windthrown P. sitchensis, 10.VII.1946 Forster (DAOM 125027).

A description of the Finnish material is enclosed here to serve as a basis for comparison with American material of the species.

Basidiocarps perennial, resupinate, finally remarkably large, ca. $70 \times 10 \mathrm{~cm}$ wide along a fallen trunk, $1.5-2 \mathrm{~cm}$ thick in the thickest part, consistency corky when fresh, woody in dry condition. Old parts 
of the basidiocarps bordered by up to $1.5 \mathrm{~cm}$ wide upper surface (pseudopileus), which is sepia-coloured at base, amber, ochraceous or rusty brown in major part and creamy white at the margin; pseudopileal margin blunt but well defined. Sterile margin of resupinate areas very narrow, undifferentiated. Pore surface creamy white in fresh condition and ochraceous cream to honey-coloured when dry, surface fairly even; pores round, (4-) 5 per mm, separated by fairly thick, sturdy dissepiments. Section: Subiculum mostly very thin in young basidiocarps, white; subiculum and old tubes disintegrate into a chalky mass in old fruit bodies. Tubes cork-coloured and sharply delimited into annual layers, which are $1-1.5 \mathrm{~mm}$ thick and number up to 7-10 or even more in the oldest part of the basidiocarp. Fresh basidiocarp with a strong and pleasant odour, taste bitter.

Hyphal system dimitic (or indistinctly trimitic), all hyphae negative in Cotton Blue. Generative hyphae with clamp connections, mostly thin-walled, but in some old parts sclerified, especially in the subiculum. Skeletal hyphae dominating in all parts, $2-2.5 \mu \mathrm{m}$ in diam, tightly packed and strongly interwoven in tube trama, hyaline, unchanged in $\mathrm{KOH}$, acyanophilous, but distinctly amyloid; skeletals unbranched in trama and in most of the subiculum, but old subiculum also bears vegetative hyphae with long branches. Granulous, resinous matter often encrusted along the hyphae. Hymenium soon degenerating and then mostly composed of cystidioles, which are abundant and vary in shape from ventricose to subulate, lanceolate or mucronate. Basidiospores short-cylindrical with a blunt, rounded distal end and sometimes slightly curved apicular region, smooth-and thin-walled, inamyloid, indextrinoid, acyanophilous, 4.6-5.7 $\mathrm{x}$ $2-2.5 \mu \mathrm{m}$.

The characters of the Finnish specimen fit well with both the published descriptions (Baxter 1938, Lowe 1966, Gilbertson 1981, Gilbertson \& Ryvarden 1986) and the Canadian specimens examined, except in a few minor details. The spores of the Canadian material agree with those of the Finnish specimen. The tightly interwoven structure of the tubes, with abundant skeletals, is evident in the Canadian specimens also, and similar cystidioles are frequently seen. The amyloid reaction of the skeletal hyphae, reported by Gilbertson (1981) and Gilbertson and Ryvarden (1986) is clear in Finnish material as well. The cystidioles seem to be shorter and less common in well-developed hymenium in good condition, but more pronounced and numerous in degenerating or otherwise loose hymenial areas. Lowe (1966) reported and illustrated 'cystidia' in the hymenium, but Gilbertson and Ryvarden (1986) did not. We in fact found rare and inconspicuous skeletocystidia (in the sense of Ryvarden 1991), which arise from the trama and protrude into the hymenium.

The pores in the American material are often slightly smaller (5-7 per $\mathrm{mm}$ ) than in our new find (ca. 5 per $\mathrm{mm}$ ), but the measurements are overlapping. Our specimen was much thicker $(20 \mathrm{~mm})$ than what the American authors report (Baxter 1938: mostly 2-3 mm, Gilbertson \& Ryvarden 1986: $6 \mathrm{~mm}$ ), but the Canadian specimen in the herbarium GB-J.E. is also fairly thick (10-13 mm). Fresh fruit bodies of our find gave off a strong, pleasant odour of menthol. Gilbertson (1981) reports that fresh basidiocarps have a strong sweet odour, and Gilbertson, Martin \& Lindsey (1974) describe the odour 'like burnt sugar cake'.

Young, still thin basidiocarps resemble Antrodia serialis (Fr.) Donk, but even they have the distinctive pleasant smell. The extensive, fairly thick fruit bodies of $A$. sitchensis bring to mind Perenniporia subacida (Peck) Donk, and the two species have similar colours: creamy pores and a fairly bright brown border on the pseudopileus. However, P. subacida has strongly dextrinoid and cyanophilous hyphae, and its spores are more isodiametric and truncate, staining strongly in Cotton Blue and Melzer's reagent.

Old basidiocarps of $A$. sitchensis disintegrate in their inner parts into a chalky mass, and white spots of mycelium are also found in rotten wood adjacent to the fungus. In this respect the species is reminiscent of Amyloporia crassa (P. Karsten) Bond. \& Singer, and the resemblance is enhanced in the microscope by the hyphal configuration and the presence of sharp cystidioles. However, A. crassa has wider spores, its sections exude oily droplets in microscopical mounts, and $\mathrm{KOH}$ makes its skeletal hyphae swell into a messy, dissolving, transparent substance. Macroscopically, they differ from each other: $A$. crassa has a white pore surface, it very seldom forms a pseudopileus and this is never brown. Nor does A. crassa have any distinctive smell.

A. sitchensis does not fit well in the genus Antrodia sensu stricto. It lacks the narrowly ellipsoid shape of the spores, seen in Antrodia heteromorpha (Fr.: Fr.) P. Karsten and its relatives, and its basidial elements are shorter and thicker-based than in Antrodia s. str. The strong odour, distinctly layered tubes, woody consistency and the presence of 'branched skeletals' (or binding hyphae) in old subiculum bring to mind the genus Fomitopsis. In Antrodia skeletal hyphae run mostly in a subparallel fashion along the tube trama or are at least straighter and more spaced; the tightly interlocked structure of $A$. sitchensis is strikingly different and would make the species fit better in Fomitopsis or Amyloporia. Affinity with 
Amyloporia is suggested by the amyloidity of the skeletals, presence of sharp-pointed cystidioles, spore shape and the degeneration of the subiculum and the oldest tube layers. However, if Antrodia is understood in the wide sense of Gilbertson and Ryvarden (1986), A. sitchensis can fit within its limits.

The Finnish specimen of $A$. sitchensis was growing on a large, fallen, and decorticated trunk of Pinus sylvestris lying on the lower slope of a shady and humid gorge. The tree was fairly strongly decayed and almost completely covered with moss. The wet and shady bottom of the gorge was occupied by mixed spruce-dominated forest with many large, fallen trunks of Picea abies and Populus tremula.

A. sitchensis is new to Finland, and this is one of the very first finds of the species outside western North America. Our identification has already been reported by Kaaro (1992). We are aware that the draft of the forthcoming book on European polypores (by Gilbertson and Ryvarden) includes an earlier record of the species in Europe. In North America it is found from Alaska and British Columbia in the north, along the Rocky Mountains to Arizona and New Mexico in the south (Baxter 1938, Gilbertson \& Budington 1970, Gilbertson, Burdsall \& Larsen 1975). An isolated record originates from New York (Gilbertson \& Ryvarden 1986).

\section{Antrodiella citrinella Niemelä \& Ryv.}

Finland. Etelä-Häme: Lammi, Evo, Kotinen virgin forest, Picea abies, Grid $27^{\circ} \mathrm{E}$ 6794:396, 8.IX.1989 Laurila \& Renvall 1982 (H, P.R.). Pohjois-Karjala: Lieksa, Patvinsuo National Park, Autiovaara, $P$. abies, Grid $27^{\circ} \mathrm{E}$ 70080:6817, 13.IX.1989 Penttilä 1223 (H, R.P., T.N.), Betula pubescens, Grid $27^{\circ} \mathrm{E}$ 70079:6814, 18.IX.1989 Penttilä 1287 (H, R.P.), P. abies, Grid $27^{\circ} \mathrm{E} 70077: 6819,19 . I X .1989$ Penttilä 1313 (H, R.P.), same tree, 2.X.1991 Penttilä 2653 (H, R.P.). Kainuu: Kuhmo, TeerisuoLososuo, P. abies, Grid 27E 70914:6091, 4.IX.1990 Penttilä 1654 (H, R.P.); Suoniemensuo, P. abies, Grid $27^{\circ} \mathrm{E}$ 7161:621, 22.IX.1991 Penttilä $2526(\mathrm{H}), P$. abies, Grid $27^{\circ} \mathrm{E} 7161: 619$, 25.IX.1991 Penttilä 2574 (H). Perä-Pohjanmaa: Rovaniemi rural commune, Pisavaara Strict Nature Reserve, Sorvannulikka, P. abies, Grid 27ㅌ 735:41, 19.IX.1981 Kotiranta 3552 (H.K.). Sompion Lappi: Savukoski, Värrio Strict Nature Reserve, $P$. abies, Grid 27ㅌE 7520:606, 15.VIII.1991 P. Renvall 2479 (H).

The species was first recorded from Finland by Niemelä and Ryvarden (1983). It is classified as vulnerable in the recent Red List of threatened animals and plants of Finland (Rassi et al. 1992). Specimen Penttilä 1287 is the first from an angiosperm. The close relationship with Fomitopsis pinicola (Swartz: Fr.) P. Karsten, noted before (Niemelä \& Ryvarden 1983), was also evident in this new material. Of the nine new Finnish records, A. citrinella was found six times growing together with $F$. pinicola, either on dead fruit bodies or close to them. Other common associate species were Amylocystis lapponica (Rom.) Singer, Fomitopsis rosea (Alb. \& Schw.: Fr.) P. Karsten and Phellinidium ferrugineofuscum (P. Karsten) Fiasson \& Niemelä, which were found three times, each time all three together, accompanying $F$. pinico$l a$ and A. citrinella. Single records were obtained from Junghuhnia collabens (Fr.) Ryv., Antrodia serialis (Fr.) Donk, Fuscoporia viticola (Schw. ex Fr.) Murr. (Phellinus viticola), Trichaptum abietinum (Pers.: Fr.) Ryv., Antrodiella cf. parasitica Vampola, Gloeophyllum sepiarium (Wulf.: Fr.) P. Karsten, Postia tephroleuca (Fr.) Jül. and Phanerochaete sanguinea (Fr.) Pouzar, but their occurrences seem coincidental. The trunk of birch was decayed by Fomes fomentarius (L.: Fr.) Fr. Once the species was found growing alone.

In most cases A. citrinella was growing on fallen, fairly thick, moss-covered trunks which were strongly decayed and often at least partly decorticated. A characteristic biotope is a moist or wet, swampy site in virgin or otherwise old and shady spruce forest.

\section{Antrodiella parasitica Vampola}

Antrodiella parasitica was recently described from Czechoslovakia (Vampola 1991). According to the description, it is a counterpart of Antrodiella semisupina (Berk. \& Curt.) Ryv. \& Johansen inhabiting coniferous trees, develops basidiocarps on fruit bodies of Trichaptum abietinum, and, unlike Antrodiella semisupina, is fully resupinate and has cystidia (in fact cystidioles).

Some records in the literature have suggested the presence of this species in the Nordic countries. Eriksson and Strid (1969) mention that "Tyromyces semisupinus (Berk. \& Curt.) Murr. is not uncommon on fallen spruces in N. Fennoscandia". Renvall et al. (1991) report "Antrodiella sp. 1" from spruces and pines in the northeastern part of Finland, often fruiting near or on dead basidiocarps of Trichaptum species. Moreover there are dozens of similar collections from eastern and northern parts of Finland. The sites are mainly undisturbed spruce dominated virgin forests, where the species grows not only on Trichaptum, but also on Fomitopsis rosea and Phellinidium ferrugineofuscum.

The Finnish material consists of specimens which are resupinate or less often pileate, the latter greatly resembling $A$. semisupina s.str. Some questions regarding the new species and its identification were raised by a study of seven specimens of $A$. parasitica from Germany (coll. I. Dunger), and Czechoslovakia (det. Vampola), several typical specimens of A. semi- 
supina from different parts of Finland, and several Antrodiella cf. parasitica from conifers.

The most typical specimens of $A$. parasitica (both Finnish and Central European) have a very thin subiculum, where the skeletal hyphae are distinctly intertwined and are less than $5 \mu \mathrm{m}$ in diam. The spores are ellipsoid, with a straight or convex ventral side, 3-3.8 $\times 2-2.8 \mu \mathrm{m}$. When such specimens of $A$. parasitica were compared with $A$. semisupina, it seemed that $A$. semisupina has thicker subiculum, wider skeletal hyphae (more than $5 \mu \mathrm{m}$ across), which run more or less parallel, and narrower, almost allantoid spores (3-3.7 x 1.5-1.9 $\mu \mathrm{m})$ with a concave ventral side. However, many specimens externally similar to $A$. semisupina and growing on angiosperms proved to have the same hyphal structure, skeletal hyphae similar to those of $A$. parasitica and spores of the same width as in A.parasitica. Moreover, all the specimens of $A$. semisupina had thin-walled cystidioles similar to those of $A$. parasitica. The division between $A$. semisupina s.str. and A. parasitica was clearer and easier to make in southern Finland, e.g. as regards the spore shape. In Central Finland the differences diminished, chiefly because the hardwood-inhabiting specimens became more and more effused and ellipsoidspored. In Lapland it is very difficult to draw a line between the two taxa. Either the difference between A. semisupina s.str. and A. parasitica has been overestimated, or there are still further taxa involved, which obscure the picture. To solve this problem, more studies and especially interfertility tests are needed.

According to Lowe (1966) "specimens from western U.S. [referred to as Poria byssina (Pers.) Rom. = Antrodiella romellii (Donk) Niemelä] were on gymnosperm substrata and differed culturally from typical Polyporus semisupinus on angiosperms". Gilbertson and Ryvarden (1986) state that "Antrodiella romellii is resupinate and grows in North America on conifers". The Finnish material of A. romellii, however, derives from deciduous trees, is totally resupinate, and has wider spores than A. parasitica, or A. semisupina.

\section{Ceriporiopsis balaenae Niemelä}

Finland. Uusimaa: Tammisaari, Jussarö, Salix aurita, dead, erect tree in a thicket, at $1 \mathrm{~m}$ height, Grid $27^{\circ} \mathrm{E}$ 6639:307, 10.X.1990 Kotiranta 9194 (H.K.). Kemin Lappi: Kemi, Pertaaapa, Grid $27^{\circ} \mathrm{E} 7299-7301: 391-4,2 . I I .1991$ Kamula (OULU), 15.II.1991 Kamula (OULU); Takajärvi, Grid 27E 7296:392, cf. Salix, 18.II.1990 Kamula (H), Alnus incana, 18.II.1990 Kamula (H), Betula sp. or Prunus padus, $5 \mathrm{~cm}$ thick trunk, 22.II.1990 Kamula (H), cf. Populus tremula, 23.II.1990 Kamula (H), cf. $P$. tremula, 23.II.1990 Kamula (H), cf. P. padus, 23.II.1990 Kamula (H). Inarin Lappi: Utsjoki, Tshieskuljoki, dead deciduous tree,
Grid $27^{\circ}$ E 7741:501, 20.VIII.1965 Laine (HFR); Kevo Subarctic Station, Salix sp., Grid 27E 7743:499, 5.IX.1970 Niemelä 408b (T.N.); Niemelä, Salix sp., hanging, dead tree in a birch-willow thicket, at riverside, Grid $27^{\circ} \mathrm{E} 7759: 504,16$.VIII.1987 Kotiranta 6371 (H, H.K.).

C. balaenae is new to Finland, and these are the first records of the species outside North America (Niemelä 1985a). The very fragile structure of the tubes and especially of the subiculum are the best characteristics differentiating $C$. balaenae from $C$. aneirina (Somm.) Donk and C. resinascens (Rom.) Dom. The species was first found close to the Arctic timberline of Quebec-Labrador, Canada. The Finnish finds do not support the conclusion that the distribution is exclusively northerly, even though the three last collections in the list (above) derive from the northernmost part of Finland. Close proximity to a humid seashore may be more characteristic of this little-known species. The host identifications of the collector Kamula are not fully reliable.

\section{Funalia trogii (Berk.) Bond. \& Singer}

Finland. Pohjois-Karjala: Ilomantsi, Pönttövaara, abundant on cut Populus tremula in young pine plantation, Grid $27^{\circ} \mathrm{E}$ 70130:7002, 5.X.1988 Mannerkoski \& Rassi (H, H.K., T.N.), 18.IX.1992 Kotiranta 10910 (H, H.K.). Other specimens examined: Russia. St. Petersburg Region: S of Svir River (Syväri), 4.IV.1944 Perttula (H). Karelian R.: ?Salarskoe, 14.VII.19?? Anonymous (H). Poland. Woj. łódzkie: Łowicz, living Populus nigra ssp. italica in a park, 12.VIII.1988 Kotiranta 6862 (H.K.). Woj. rzeszowskie: Ustrzyki Dolne, town centre, on big stump of Salix sp., open and dry site, 26.VII.1969 Niemelä $336 b$ (T.N.). China. Beijing, 14.IX.1982 Han et al. (H, ex HMAS 39568).

The description is based on the basidiocarps collected from Finland.

Fruit body annual, pileate, semicircular or elongated and broadly attached to the substrate, up to $12 \mathrm{~cm}$ wide, projecting $2-4 \mathrm{~cm}$ horizontally from the wood; base up to $4 \mathrm{~cm}$ thick. Profile of the thick fruit bodies triangular, of the thinner ones wedge-shaped. Pileus covered by 1-2 mm long hairs, which are basally almost white, but at the apex greyish or light rusty brown; in young fruit bodies the surface is evenly hirsute, in old ones clearly porous between the agglutinated tufts of hair, which give the fruit body a rough appearance. The hair-tufts turn pale brown to dark brown when treated with $\mathrm{KOH}$. Border sharp. Pores fairly large, 15-20 per $\mathrm{cm}$, pore surface dark honeycoloured, lighter towards the border. Section: Context clearly radially fibrous, pale greyish ochre, darkening to brown when treated with $\mathrm{KOH}$ and turning pale greyish lilac when the spot has dried. The tubes up to $1 \mathrm{~cm}$ long, of the same colour as the context but 
lighter, colour change varying from nil (young fruit bodies) to strong (old fruit bodies) when treated with $\mathrm{KOH}$.

Hyphal system trimitic. Context: Generative hyphae thin-walled, inamyloid, indextrinoid, acyanophilous, with clamp connections, (2-)2.3-2.5(-4) $\mu \mathrm{m}$ in diam. The context dominated by subparallel, radially arranged, unbranched skeletal hyphae, which are thick-walled (walls up to $2 \mu \mathrm{m}$ ), slightly dextrinoid(?) and cyanophilous, and turn bluish green-lilac in Cresyl Blue, (4-)4.5-6(-6.5) $\mu \mathrm{m}$ in diam. Among the true skeletals are almost similar hyphae, which run several hundreds of $\mu \mathrm{m}$ :s without branching, but bear a few, fairly short, apical side branches. Binding hyphae $2-3.5 \mu \mathrm{m}$ in diam, hyaline, indextrinoid, acyanophilous, of two types: (1) cells starting from a clamp, with a fairly long $(70 \mu \mathrm{m})$ unbranched part, and ending in a much-branched, arboriform "crown", and (2) cells starting from a clamp and lacking the long unbranched part; such hyphae are also much branched, but the branches are relatively short. Trama: Generative hyphae thin-walled, with clamp connections, (3-)3.2-3.8(-4) $\mu \mathrm{m}$ in diam. Skeletals fairly few, thick-walled (walls up to $1.8 \mu \mathrm{m}$ ), slightly dextrinoid, cyanophilous, $3.7-5.5 \mu \mathrm{m}$ in diam. Binding hyphae dominating in the trama, (1.7-)2-2.4 $\mu \mathrm{m}$ in diam. Basidiospores cylindrical, smooth- and very thinwalled, inamyloid, indextrinoid, acyanophilous, $6.9-9 \times 2.5-3.5 \mu \mathrm{m}$.

In the Finnish sporocarps the hymenium was destroyed, so that no basidia were seen. Only a few spores could be observed.

The generic position of the present species has been controversial, and no clear criteria have been found to support preference of one solution to another. The species has an irritatingly intermediate position between two generic groups: that formed by Trametes (type: Polyporus suaveolens L.: Fr.), Coriolus (type: $P$. versicolor L.: Fr.) and Funalia (type: $P$. mons-veneris Jungh. $=P$. leoninus $\mathrm{Klotzsch}$ ), having a white context, and the group formed by Coriolopsis (type: $P$. occidentalis Klotzsch $=C$. polyzona (Pers.) Ryv.) and Trametella (type: $P$. gallicus Fr.) having a brownish or ochraceous context. Species of all these genera cause a white rot, and they have a trimitic hyphal system and fairly similar spores.

The colour of the context may not be a reliable basis for separating the genera, especially because, as pointed out by Corner (1989), there are many intermediate species in Coriolopsis, with pale ochraceous, pale brown or pinkish context. Ryvarden (1978) and Gilbertson and Ryvarden (1986) include $F$. trogii in Trametes, because the context is not clearly brown.

When the context of $F$. trogii is treated with $\mathrm{KOH}$ it reacts by turning brown, similarly to the context of
Funalia leonina (Klotzsch) Pat., Coriolopsis gallica (Fr.) Ryv. and C. polyzona. The context of Trametes suaveolens (L.: Fr.) Fr. does not change its colour in $\mathrm{KOH}$.

Cotton Blue and Cresyl Blue provided even stronger support for placing the present species in Funalial Coriolopsis and excluding it from Trametes. Trametes suaveolens, T. hirsuta (Wulf.: Fr.) Pilát, T. gibbo$s a$ (Pers.) Fr. and $T$. versicolor (L.: Fr.) Pilát, among others, are negative in Cotton Blue and Cresyl Blue. By contrast, the skeletals of $F$. trogii are cyanophilous and metachromatic, like the skeletals of $C$. polyzona and $C$. gallica. The cvanophily of the skeletal hyphae is in our opinion the best and most reliable character differentiating Funalia/Coriolopsis from Trametes.

The delimitation of Coriolopsis from Funalia is difficult. There seems to be a continuous transition from the white-context Funalia leonina (Ryvarden \& Johansen 1980) to the consistently brown-context species of Coriolopsis, all of them having similar reactions to Cotton Blue and other reagents. The genus name Funalia was described earlier (Patouillard 1900) than Coriolopsis (Murrill 1905). Unless some new separating criteria are found, we prefer to merge Coriolopsis in Funalia.

Other differences may be found between Trametes and Funalia. European species of Trametes have a corky, not fibrous context, due to strongly interwoven skeletals and binding hyphae in the fruitbody context. The species of Funalia seem to have a fibrous context. In Trametes, there is a sharp cortical line which divides the corky context and the layer of hairs above it. In Funalia the transition from the fibrous context to the hairy cover of the pileus is gradual, without a delimiting layer.

In Finland the identification of $F$. trogii poses no problems. Trametes hirsuta is thinner, its pore layer is grey in mature specimens and the pores are smaller (4 per $\mathrm{mm}$ ). F. gallica (Fr.) Bond. \& Sing., which has often been confused with $F$. trogii, is darker (especially the context), it has much larger pores (9-13 per $\mathrm{cm})$ and the spores are about $11-14 \times 3.5-4.5 \mu \mathrm{m}$ (Canada: British Columbia, Summerland, Res. Station, 30.X.1935 McCallum, H, ex DAOM F6005), while in F. trogii they are 9-10 × 3-3.5 $\mu \mathrm{m}$ (Kotiranta 6862). F. gallica has not been found in Finland. The characters of the Finnish specimens of $F$. trogii agree well with the descriptions from Europe (Bourdot \& Galzin 1928, Jahn 1963, Ryvarden 1978) and North America (Overholts 1953, Gilbertson \& Ryvarden 1987).

$F$. trogii is very rare in the Nordic countries. It has been reported from Norway (Ryvarden 1978) and Sweden (Strid 1979). In adjacent Russia, the species has been reported from the Murmansk Region and 


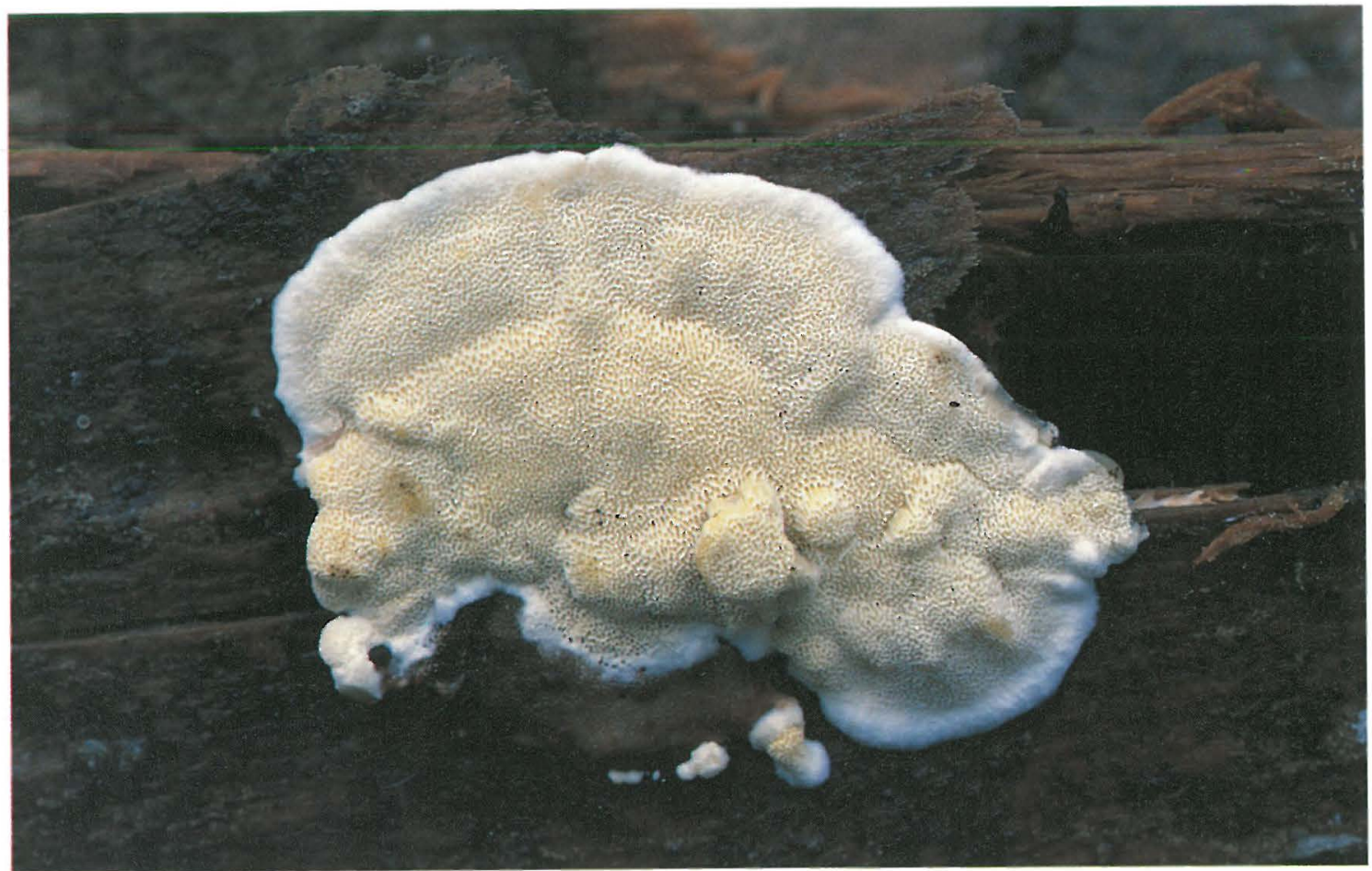

Fig. 2. Antrodiella citrinella Niemelä \& Ryv., fresh specimen. Kotiranta 3552, x 2.7 (H.K.).

Karelia (Shubin \& Krutov 1979), and we here add two further records. Järva and Parmasto (1980) reported it from Estonia. Elsewhere in Europe $F$. trogii is rare, but has been reported, from France (Bourdot \& Galzin 1928), Spain (Dueñas \& Tellería 1988), Germany (Jahn 1963, Kaspar 1977, Kreisel 1987), Switzerland (Breitenbach \& Kränzlin 1986), Czechoslovakia (Kotlaba 1984), Poland (Domański et al. 1973), the Netherlands (Jülich 1984), Russia (Bondartsev 1953) and the Ukraine (Zerova et al. 1972). Outside Europe $F$. trogii is widely distributed in Siberia (Stepanova-Kartavenko 1967), Kazakhstan (Shvartsman 1964) and Iran (Hallenberg 1981). The distribution in North America covers the continent from Alaska in the west to Nova Scotia in the east, and to California and Arizona in the south (Overholts 1953, Gilbertson \& Ryvarden 1987).

The host tree mentioned by most authors is Populus tremula, but records from other hardwoods (Salix, Acer, Betula, Fagus and Ulmus) also exist (e.g. Overholts 1953, Ginns 1986, Kreisel 1987). Shvartsman
(1964) gives a long list of hosts from Kazakhstan, and the only note from a conifer is from Pinus (Zerova et al. 1972).

The Finnish locality is in the Middle Boreal subzone (see Niemelä 1982a) in eastern Finland about 15 $\mathrm{km}$ from the Russian border. The climate is slightly continental or indifferent (Ahti et al. 1968). The dead host tree was situated in an about 15-year-old plantation of Pinus sylvestris, just at the border of a virgin forest dominated by Picea abies, in a Vaccinium myrtillus site type. The place was studied by H.K. in autumn 1990, but $F$. trogii was not refound. However, the locality harboured other rare wood-rotting fungi, such as Gloiodon strigosus (Schwarz: Fr.) Karst. and Hericium coralloides (Scop.: Fr.) Pers. in the young pine forest. The old spruce forest was very rich in polypores, and many species which grow almost solely in virgin forests were noted, e.g. Fomitopsis rosea, Phellinidium ferrugineofuscum, Porodaedalea chrysoloma (Fr.) Fiasson \& Niemelä, Phellinus laevigatus (P. Karsten) Bourdot \& Galzin, P. nigrolimitatus 
(Rom.) Bourdot \& Galzin and Gelatoporia pannocincta (Rom.) Niemelä. The northerly Daedaleopsis septentrionalis (P. Karsten) Niemelä is here at its southern border and Trichaptum pargamenum (Fr.) Cunningham enriches the polypore flora with an eastern element.

F. trogii was found again by H.K. in 1992 in the original site. Abudant fruit bodies emerged from a fallen trunk of aspen, decorticated and ca. $60 \mathrm{~cm}$ in diam. Antrodiella semisupina was growing among $F$. trogii, even arising from dead fruit bodies of the latter.

This is the first Finnish record of $F$. trogii, which is a threatened species in several European countries. $F$. trogii is classified as endangered in Finland (Rassi et al. 1992), Sweden (Anonymous 1991), Norway (Bendiksen \& Høiland 1991) and East Germany (Benkert 1982), as threatened, rare in the Netherlands (Arnolds 1989) and in South and West Germany (Winterhoff 1984), and threatened, indeterminate in Poland (Wojewoda \& Eawrynowicz 1986). Gloiodon strigosus, Gelatoporia pannocincta and Trichaptum pargamenum are also threatened in Finland (Rassi et al. 1992). Moreover, the old forest has a very rich fau-na of beetles (Coleoptera), with about 25 threatened species; for instance it contains the only known population of Ipidia sexguttata (F. Sahlberg) (Nitudulidae) in Finland (Rassi 1989).

\section{Perenniporia tenuis (Schw.) Ryv. var. pulchella (Schw.) Lowe}

Finland. Etelä-Häme: Tammela, Heinämaa, Alnus, Grid $27^{\circ} \mathrm{E}$ 674:32, 27.IX.1879 Karsten (holotype of Physisporus vitellinus P. Karsten, H 2851, 2852). Pohjois-Karjala: Lieksa, Patvinsuo National Park, Autiovaara-Rauvunvaara, Populus tremula, Grid 27E 70081:6806, 20.IX.1989 Penttilä 1342 (H, T.N.). Other specimens examined: Austria. Steiermark: Neumarkt, Oberdorf, Betula pendula, alt. $1000 \mathrm{~m}, 12 . \mathrm{VI} .1990$ Forstinger (PRM 870281). Tyrol: Achensee, Falzthurntal, Picea, 6.VIII.1982 David 4322 (O-L.R.). Canada. Yukon: Whitehorse, Miles Canyon, Populus tremuloides, 26.IX.1987 Niemelä 4112 \& Huhtinen (T.N.). U.S.A. Arizona: Coconino, Karbal Nat. Forest, $P$. tremuloides, 20.VIII.1973 Lindsey 268 (O-L.R.). China. Jilin: Chang Bai Shan Forest Res., Corylus, 11.IX.1983 Ryvarden 21322 (O-L.R.). Nepal. Gandaki: Ghorapani, 30.X.1979 Ryvarden 18639 (O-L.R.). Japan. Honshu: Shizuoka, Mt. Fuji, Quercus crispula, 10.VIII.1948 Imazeki 618 (O-L.R.).

The genus Perenniporia is very well defined, but the species concepts pose confusing discrepancies. The best characters for determination have not always been utilized, and identifications have been based on pore surface colours, pore sizes, spore shapes, spore wall thicknesses, etc., which are variable or difficult to measure, or difficult to describe without risk of misinterpretation.

We have compared the North and Central European taxa and give here very preliminary results, which may help in making further studies. The pileate species (Perenniporia ochroleuca (Berk.) Ryv. and $P$. fraxinea (Bull.: Fr.) Ryv.) are omitted, as is also $P$. narymica (Pilát) Pouzar, characterized by amyloid skeletal hyphae which dissolve in KOH. The Mediterranean $P$. rosmarini David \& Malençon is also excluded from this discussion. It is an annual, thin polypore with very small pores (up to 8 per mm), inhabiting Rosmarinus and other shrubs of the dry macchia vegetation (Bernicchia 1990).

The remaining taxa, compared in this study are: Perenniporia fulviseda (Bres.) Dhanda, P. medullapanis (Jacq.: Fr.) Donk, $P$. subacida, $P$. tenuis var. pulchella, and $P$. tenuis var. tenuis. We are not sure, whether the $P$. tenuis var. tenuis of the European authors is the same as that of the American authors. Therefore the name is written here as 'tenuis' and it means the Central European material only. Both the names tenuis and pulchella were originally described from North American collections.

The five taxa of Perenniporia can be identified by their general appearance, colour spectra and details in their ecological and host relationships, but only after ample experience. There are slight differences in pore sizes, but the values overlap. $P$. fulviseda is characterized by somewhat smaller pores than the others. Keller (1986) published a description and a beautiful colour photograph of $P$. fulviseda. Other characters are the consistency of dry fruit bodies, $P$. subacida being soft-corky and light-weight, while the others are hard and woody and feel heavier in the hand. P. subacida is creamy white when fresh, but turns ochraceous when drying. $P$. tenuis var. pulchella is bright chrome or lemon yellow or vitelline when fresh, but its hues fade somewhat upon drying. P. medulla-panis and $P$. 'tenuis' keep their colours best. $P$. medulla-panis is almost white but has a faint salmon or orange tint deep in the tubes; the areas which lack the pores, i.e. margins and steps of sloping areas, are brighter yellow or orange-brown. P. 'tenuis' is basically white, too, but there is usually a distinct ash-grey or lilac-grey tint deep in the tubes.

In some cases the spore dimensions offer a distinction (see Table 1), but equally often their differences are too small to be used: besides, the spores collapse very soon in Perenniporia, obscuring the exact ranges of variation.

The best characters are mostly found in the skeletal (or skeleto-binding) hyphae of the tube trama: hyphal orientation, diameter of the hyphae, tendency to 
agglutinate or to stay separate, and the colour reactions in Melzer's Reagent (IKI) and Cotton Blue (CB). We recommend that two sets of thin vertical sections be made from the tubes and mounted in IKI and $\mathrm{CB}$.

The important differences between the five taxa are listed in Table 1. Two groups of species are found, (1) those whose hyphae are strongly interwoven in the tubes ( $P$. medulla-panis and $P$. fulviseda) and (2) those whose hyphae are longitudinally oriented or parallel.

(1) The reactions in IKI and especially in $\mathrm{CB}$ differentiate $P$. fulviseda (strong reactions) from $P$. medulla-panis (skeletal hyphae indextrinoid and $\mathrm{CB}$ - or very faintly $\mathrm{CB}+$, and hyphal lumina sometimes amyloid, IKI blue-grey, especially where the hyphae are branching). The set of reactions in P. medullapanis is unique in this genus.

(2) The second group consists of taxa whose tube skeletals have a longitudinal orientation. Of them, $P$. subacida is recognized by its broader hyphae, which - although having fairly thick walls - have very wide lumina. Besides, the spores of $P$. subacida are smaller than those of $P$. 'tenuis' and var. pulchella. The biggest problems are involved in the two lastmentioned taxa.

Both $P$. 'tenuis' and var. pulchella have been accepted in the European flora of polypores (Kotlaba 1984, Kuthan \& Kotlaba 1981, 1988, Kotlaba 1976), the former being a thermophilous species of oaks, Robinia and other hosts on dry hills of Central Europe and southwards. Var. pulchella is a very rare

Table 1. A compilation of some microscopical characteristics which differentiate five taxa of Perenniporia. The term 'capillary' means that the lumen occupies distinctly less than $1 / 3$ of the hyphal diameter. Some important characters are in bold face.

\begin{tabular}{|c|c|c|c|c|c|}
\hline & fulvisèda & medulla-panis & subacida & $\begin{array}{l}\text { tenuis sensu } \\
\text { European auct. }\end{array}$ & $\begin{array}{l}\text { tenuis var. } \\
\text { pulchella }\end{array}$ \\
\hline $\begin{array}{l}\text { Spores } \\
\mu \mathrm{m}\end{array}$ & $\begin{array}{l}(4.2-) 4.3-5.1 \times \\
(3-) 3.2-3.7(-3.8)\end{array}$ & $\begin{array}{l}(4.6-) 4.7-5.5(-6.1) \times \\
3.5-4.2(-4.8)\end{array}$ & $\begin{array}{l}(4.4-) 4.8-5.7(-6) x \\
(3.2-) 3.5-4.4(-4.9)\end{array}$ & $\begin{array}{l}6-7.3(-7.5) \times \\
(4.6-) 4.8-5.8 \\
(-6)\end{array}$ & $\begin{array}{l}(5-) 5.8-6.9 x \\
3.4-4.3(-4.8)\end{array}$ \\
\hline $\begin{array}{l}\text { Spore } \\
\text { staining }\end{array}$ & $\begin{array}{l}\text { strongly IKI red } \\
\text { strongly } \mathrm{CB}+\end{array}$ & $\begin{array}{l}\text { strongly IKI red } \\
\text { strongly } \mathrm{CB}+\end{array}$ & $\begin{array}{l}\text { strongly IKI red } \\
\text { strongly } \mathrm{CB}+\end{array}$ & $\begin{array}{l}\text { strongly IKI red } \\
\text { strongly CB+ }\end{array}$ & $\begin{array}{l}\text { very faintly } \\
\text { IKI pinkish; } \\
\text { strongly } C B+\end{array}$ \\
\hline $\begin{array}{l}\text { Skeletal } \\
\text { hyphae } \\
\text { in tubes }\end{array}$ & $\begin{array}{l}(1.1-) 1.3-1.7 \mu \mathrm{m} \\
\mathrm{IKI} \text { red, } \mathrm{CB}+\end{array}$ & $\begin{array}{l}1-2.1(-2.8) \mu \mathrm{m} \text {, } \\
\text { walls IKI-, lumen } \\
\text { sometimes IKI } \\
\text { blue, walls CB- } \\
\text { or } \mathrm{CB}(+)\end{array}$ & $\begin{array}{l}(2.4-) 2.9-4.5(-5) \mu \mathrm{m} \text {, } \\
\text { IKI red, CB+ }\end{array}$ & $\begin{array}{l}(1-) 1.8-2.5 \\
(-3.3) \mu \mathrm{m}, \mathrm{IKI} \\
\text { light brown, } \\
\mathrm{CB}+\end{array}$ & $\begin{array}{l}(1.3-) 1.8-3 \\
(-4) \mu \mathrm{m}, \\
\text { IKI yellow, } \\
\mathrm{CB}+\end{array}$ \\
\hline $\begin{array}{l}\text { Orientation } \\
\text { of skeletal } \\
\text { hyphae } \\
\text { in tubes }\end{array}$ & $\begin{array}{l}\text { strongly inter- } \\
\text { woven, } \\
\text { no orientation }\end{array}$ & $\begin{array}{l}\text { strongly inter- } \\
\text { woven, } \\
\text { no orientation }\end{array}$ & $\begin{array}{l}\text { almost parallel, } \\
\text { hyphae straight, } \\
\text { separate, distinct }\end{array}$ & $\begin{array}{l}\text { irregularly sub- } \\
\text { parallel, glued } \\
\text { into bundles }\end{array}$ & $\begin{array}{l}\text { loosely paral- } \\
\text { lel, hyphae } \\
\text { straight, sepa- } \\
\text { rate, distinct }\end{array}$ \\
\hline $\begin{array}{l}\text { Wall/lu- } \\
\text { men ratio } \\
\text { in skeletal } \\
\text { hyphae }\end{array}$ & capillary & capillary & $\begin{array}{l}\text { walls fairly thin } \\
\text { to thick, lumen } \\
\text { very wide }\end{array}$ & capillary & $\begin{array}{l}\text { walls thick, } \\
\text { lumen distinct } \\
\text { and regular }\end{array}$ \\
\hline $\begin{array}{l}\text { Pores } \\
\text { per } \mathrm{mm}\end{array}$ & $6-7$ & $4-5$ & $4-6$ & $(3-) 4-5$ & $(3-) 4-5$ \\
\hline
\end{tabular}




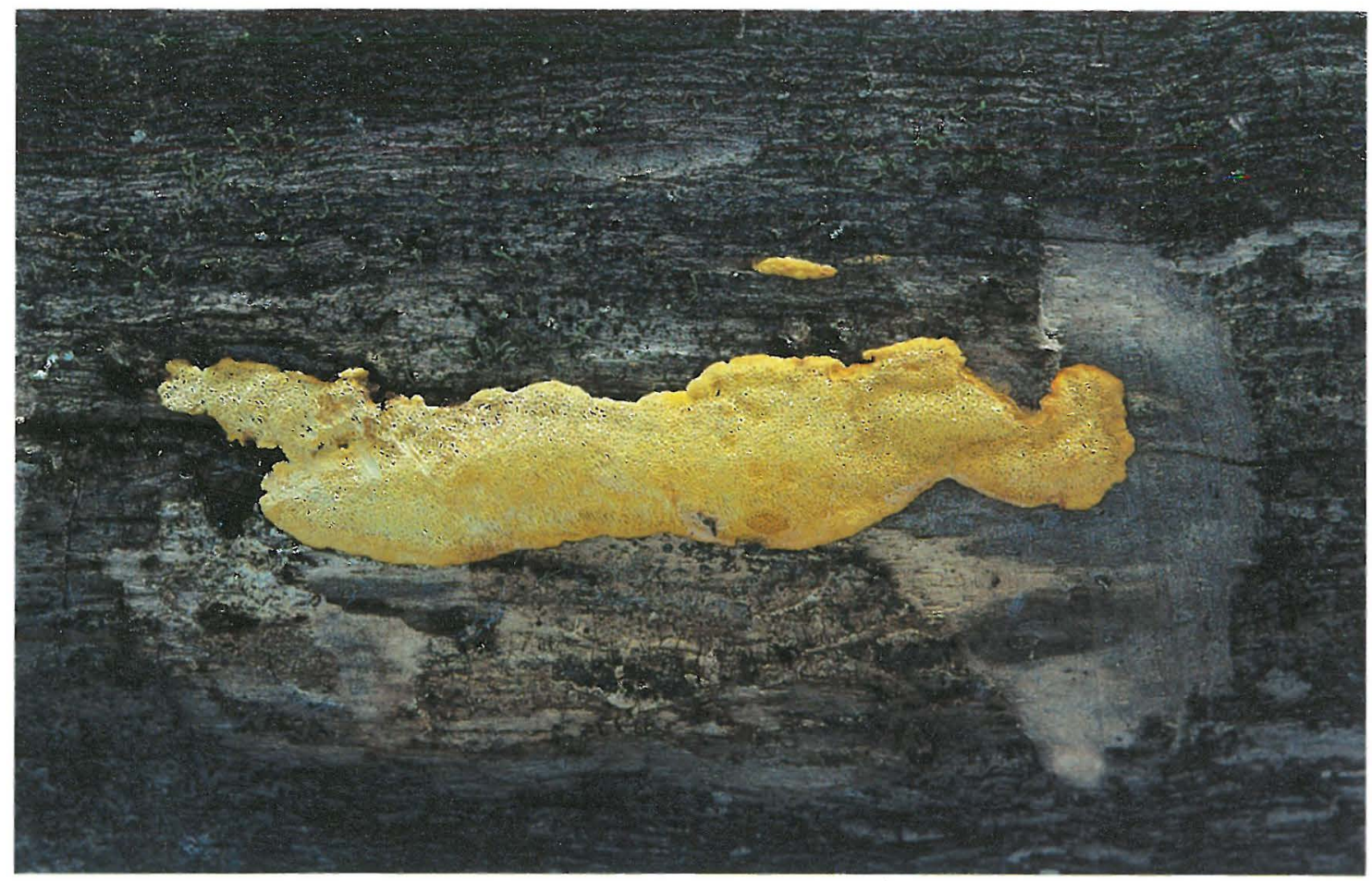

Fig. 3. Perenniporia tenuis (Schw.) Ryv. var. pulchella (Schw.) Lowe, young fruit body on fallen aspen. Penttilä $1342, \times 1.2(\mathrm{H})$.

taxon, having isolated occurrences in different parts of Europe (Klán \& Kotilová-Kubičková 1982, Ryvarden 1978). When $P$. 'tenuis' and var. pulchella are compared, distinct differences are found in the hyphal construction, especially in the tubes (see Table 1). The straight, separate, clean and easily studied skeletals of var. pulchella differ from the agglutinating, winding, thinner skeletals of $P$. 'tenuis'. The spores of var. pulchella assume only a faint reddish tint in IKI or remain almost unstained; the spores of 'tenuis' stain intensive red-brown in IKI and make a striking contrast to the yellowish hyphae. Considering these characters together with the external differences and different ecology and distribution, we find it difficult to accept these two taxa under a single species.

The specimens of var. pulchella from Europe, Asia and America seem to be conspecific. It is possible that in North America P. tenuis var. tenuis and var. pulchella really are the extremes of a colour variation within a single species; Gilbertson and Ryvarden (1987) report them to be interfertile there. This would mean that $P$. 'tenuis' in Europe is in fact another, perhaps unnamed species. We did not find it in the American material.

Var. pulchella was found on Alnus incana in western Finland by Karsten (1879), who described it as Physisporus vitellinus. The taxon was subsequently not found in this country for over a hundred years, and it was considered to be extinct (Rassi et al. 1986). Now it has been refound in easternmost Finland on fallen, strongly decayed Populus tremula in moist and shady mixed forest. It is classified as endangered (Rassi et al. 1992) in the revised Red List.

\section{Piloporia sajanensis (Parm.) Niemelä}

Finland. Etelä-Savo: Ruokolahti, Virmujoki, Lampila road, Pinus sylvestris, Grid 27E 6805:596, 4.VI.1964 Laine \& Poutanen (H, HFR). Kainuu: Kuhmo, Suoniemensuo, Picea abies, fallen trunk in old, spruce-dominated swamp near and on dead Trichaptum laricinum, also dead Antrodia serialis, Fomitopsis rosea and Porodaedalea chrysoloma (Phellinus c.) in the same trunk, Grid $27^{\circ} \mathrm{E}$ 71602:6209, 17.IX.1991 Penttilä 2476 (H, R.P.). 


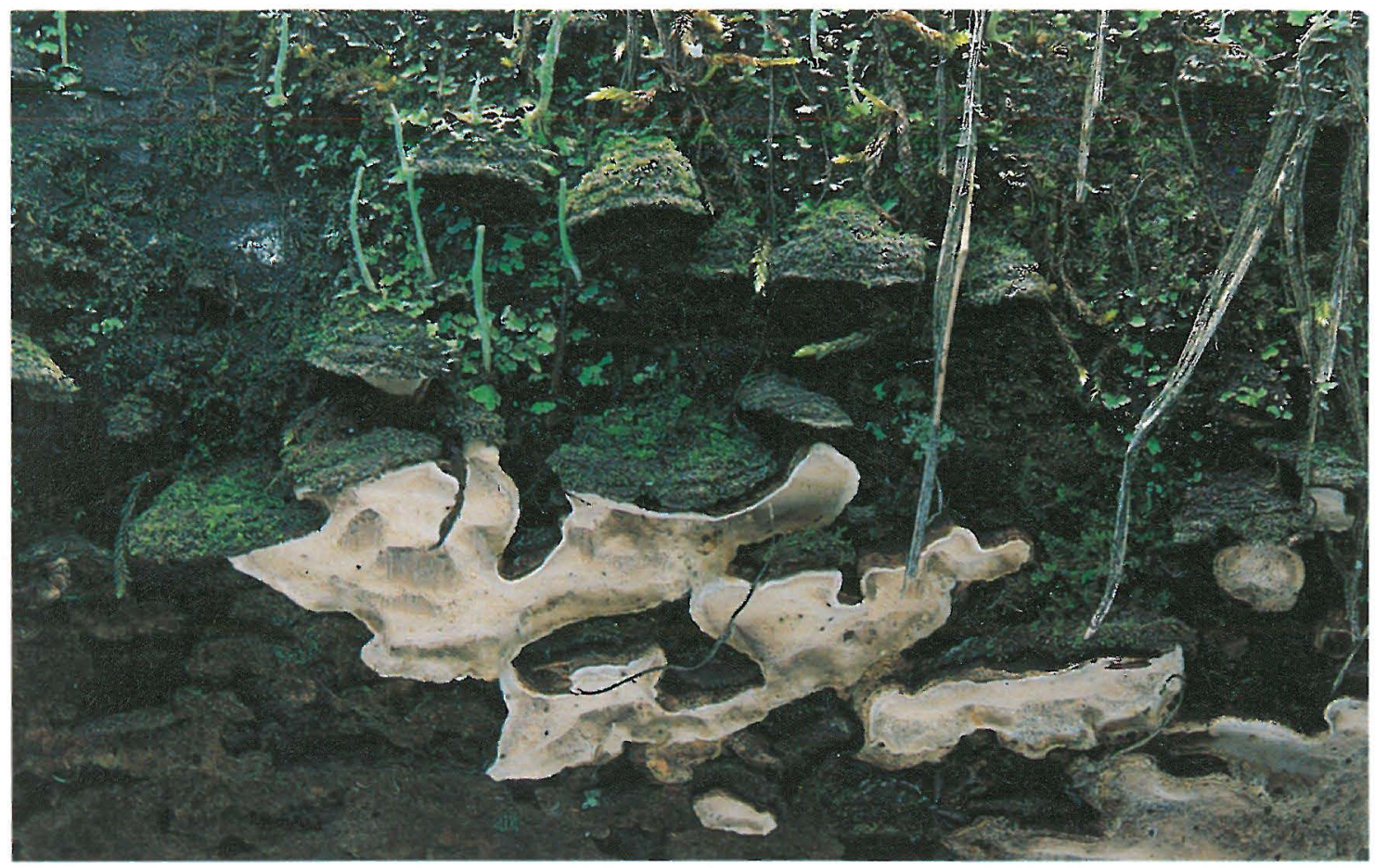

Fig. 4. Piloporia sajanensis (Parm.)Niemelä, photographed in situ. Fruit bodies (pale) growing below and on dead Trichaptum laricinum (P. Karsten) Ryv. Penttilä 2476, x $1.2(\mathrm{H})$.

This species was first recorded from Finland by Niemelä (1982b), and Renvall et al. (1991) reported two new collections from northeastern Finland; they are not repeated here. $P$. sajanensis seems to be an extreme rarity throughout its range: it is known from two collections in Sweden (Strid 1981, Ryvarden 1986), one in European Russia and three collections in Siberia (Parmasto 1962, 1967). In Finland Picea abies is a slightly more favourable host ( 3 finds in all) than Pinus sylvestris (2 finds). Trichaptum laricinum (P. Karsten) Ryv. was the commonest associate species, in three cases; its distributional pattern is boreocontinental (see Renvall et al. 1991). P. sajanensis seems to be at least slightly boreo-continental, too, although the two new records from Finland, and one new find from Sweden (Ryvarden 1986) extend its range distinctly southwards. The above-listed Finnish records derive from the slightly continental easternmost frontier of the country. The specimen Penttilä 2476 bears beautiful pilei, dark sepia brown, up to 70 $\mathrm{mm}$ wide, and projecting $15 \mathrm{~mm}$ from the substrate.

\section{Polyporus pseudobetulinus (Pilát) Thorn et al.}

Finland. Pohjois-Karjala: Kuhmo, Hiidenportti NW, Uuronvaara $\mathrm{N}$ slope, Populus tremula in a large clear-cut area, Grid $27^{\circ} \mathrm{E} 7086: 632$, 28.VII.1992 Tynkkynen (H). Lieksa, Savijärvi, Saarvavaara, $P$. tremula in rich, spruce-dominated forest, alt. $217 \mathrm{~m}$, Grid $27^{\circ} \mathrm{E} 706321: 63317,12$. VII.1992 Tynkkynen \& Sorvari (H). Lieksa, Juurikkavaara, $1.7 \mathrm{~km}$ SE Haapavaara farm, $P$. tremula in rich spruce-dominated forest, alt. $230 \mathrm{~m}$, Grid $27^{\circ}$ E 772270:30665, 29. VII.1992 Sorvari (H). Nurmes, Hiidenportti NW, Repokangas ESE, Louhivaara; $P$. tremula in large clear-cut area, Grid $27^{\circ} \mathrm{E}$ 7088:631, 28.VII.1992 Tynkkynen (H). Kainuu: Sotkamo, Porkkasalo, Porkkavaara SW slope, living $P$. tremula in rich spruce-dominated virgin forest, alt. 215 m, Grid 27E 70868:6047, 16. \& 30.VI.1992 Koivisto \& Sauso. Other specimen examined: Russia. Karelian R.: Pudozh Region, Vodlozerski National Park, W slope of Novgude Hill, big, dead $P$. tremula, five fruit bodies $8-10 \mathrm{~m}$ above ground level 23.VII. 1992 Lindholm, Heikkilă \& Suoknuuti (H).

The distribution of Polyporus pseudobetulinus (Piptoporus pseudobetulinus (Pilát) Pilát) in Europe, Asia and $\mathrm{N}$ America was recently summarized by Thorn et al. (1990). So far the only known extant 
occurrence was in northwestern Finland (Niemelä \& Kotiranta 1991). An extensive survey of virgin forests (Old Forest Inventory Programme) in East Finland in the summer of 1992 revealed these new localities of $P$. pseudobetulinus. The species is extremely rare throughout its range, and is classified as endangered in Finland (Rassi et al. 1992).

The weather in 1992 was very dry and sunny from May to June, but otherwise the season was normal. Surprisingly, all the above Finnish records were made from aspen trees which had been gridled (debarked at the base) to prevent the growth of root suckers. It seems as if the sudden death of the host would cause a final flush of fruiting. The trees were standing and all except the one from Sotkamo were dead. The sites were, or had been before clear-cutting, very rich. The Russian record is new.

The new Finnish finds were made by amateur biologists, taking part in the inventory. They were either trained in identification courses of polypores, where threatened species are especially pointed out, or had read about the species in popular articles and Finnish identification guides (Kotiranta 1989, Niemelä 1991, Manninen 1992).

\section{Skeletocutis lilacina David \& Keller}

Finland. Pohjois-Karjala: Lieksa, Patvinsuo National Park, Lahnasuo, Picea abies, fairly hard, corticated, fallen trunk in swampy place, many fallen spruces and pines nearby, associated with Trichaptum abietinum and Fomitopsis pinicola in the same trunk, Grid $27^{\circ} \mathrm{E}$ 70074:6826, 26.IX.1989 Penttilä $1385(\mathrm{H}$, R.P.), same tree, 1.X.1990 Penttilä 1920 (R.P.), same tree, 3.X.1991 Niemelä 5562 (T.N.).

Kotiranta (1986) published the first record of S. lilacina from Finland. This new find is to our knowledge the second made in Fennoscandia. The species is also known from Switzerland (David \& Keller 1984) and Canada (Niemelä 1985a).

\section{Tyromyces canadensis Overh. ex Lowe}

Finland. Pohjois-Karjala: Lieksa, Patvinsuo National Park, Rauvunvaara, Pinus sylvestris, big, strongly decayed, mosscovered, fallen trunk beside swamp, associated with Junghuhnia luteoalba, Grid $27^{\circ} \mathrm{E}$ 70075:6807, 19.IX.1989 Penttilä 1321 (H, R.P., T.N.). Inarin Lappi: Inari, Lemmenjoki National Park, Ravadasköngäs, Pinus sylvestris, big, old, decorticated, fallen trunk by the river, Grid $27^{\circ} \mathrm{E} 7622: 457,2 . I X .1981$ Kotiranta 2986 \& Koski (H.K.).

The first reports of this species from Europe were made simultaneously by Niemelä (1985b) and Schmid-Heckel (1985) from Finland and Switzerland, respectively. The last-mentioned author published a colour photograph of the species in fresh condition. Ryvarden and Gilbertson (1984) include this species in the genus Antrodiella (as A. overholtsii), but in our opinion it is a typical Tyromyces sensu stricto. For instance, the contextual hyphae are almost indistinguishable from those of Tyromyces chioneus (Fr.) Karst., and the cyanophily of the hyphae, characteristic of Antrodiella, is not seen in $T$. canadensis.

T. canadensis is a rarity in Europe. Elsewhere it is known only from North America (Gilbertson \& Ryvarden 1986), from a few localities in the northern states of the U.S.A and from Canada. In Finland it is classified as vulnerable in the newest Red List (Rassi et al. 1992). Niemelä (1985b) presumed T. canadensis to be northern in its general distribution, and the new collections support this view. The Swiss specimen was found in a mountainous area $1560 \mathrm{~m}$ above sea level (Schmid-Heckel 1985) and that altitude corresponds to the Middle or Northern Boreal zone. The Finnish collections derive from the Northern Boreal or Middle Boreal zone, or from a transitional area between them. The finds are from the most continental parts of Finland and $T$. canadensis might be a boreocontinental species. In Finland $T$. canadensis has been found only on Pinus sylvestris, in Switzerland it was found on Picea abies (Schmid-Heckel 1985) and in North America it was also found on coniferous trees, for instance Picea glauca (Niemelä 1985b). It seems that $T$. canadensis requires a moist and fairly constant microclimate.

Acknowledgements. We thank Ingrid Dunger (Görlitz), Ilpo Mannerkoski (Helsinki), Pertti Rassi (Helsinki), Pertti Renvall (Helsinki), Leif Ryvarden (Oslo) and Petr Vampola (Jihláva) for placing specimens at our disposal. Herbarium material was also obtained from DAOM, GB-J.E., HFR, OULU, and PRM, and we thank the curators and other researchers who helped in organizing loans. T.N. is indebted to Zdeněk Pouzar (Praha) for lengthy discussions on Perenniporia, and many clues to finding differentiating characters were provided by Dr. Pouzar. Ms. Anna A. Damström, M. A., revised the English. This study is a contribution to Project No. 1011799 (1991-1993) of the Academy of Finland. The travel and field-work expenses of R.P. were paid by the Finnish National Board of Forestry and the Kone Foundation.

\section{References}

Ahti, T., Hämet-Ahti, L. \& Jalas, J. 1968: Vegetation zones and their sections in northwestern Europe. - Ann. Bot. Fennici 5:169-211.

Anonymous 1991: Kommenterad lista över hotade svampar i Sverige. Floravårdskommittén för svampar. - Windahlia 19:87-130.

Arnolds, E. 1989: A preliminary red data list of macrofungi in the Netherlands. - Persoonia 14:77-125.

Baxter, D.W. 1938 ('1937'): Some resupinate polypores from 
the region of the Great Lakes 9. - Pap. Michigan Acad. Sci. Arts Lett. 23:285-305.

Bendiksen, E. \& Høiland, K. 1991: Rare and threatened macromycetes in Norway. A preliminary list. $-4 \mathrm{pp}$. NINA, Oslo (manuscript).

Benkert, D. 1982: Vorläufige Liste der verschollenen und gefährdeten Grosspilzen der DDR. - Boletus 6:21-32.

Bernicchia, A. 1990: Polyporaceae s.l. in Italia. - 594 pp. Ist. Patol. Veg., Bologna

Bourdot, H. \& Galzin, A. 1928 ('1927'): Hyménomycètes de France. Hetérobasidiés - Homobasidiés gymnocarpes. 762 pp. Soc. Mycol. France, Sceaux.

Breitenbach, J. \& Kränzlin, F. 1986: Fungi of Switzerland 2. Non gilled fungi. Heterobasidiomycetes, Aphyllophorales, Gastromycetes. - 412 pp. Verlag Mykologia, Lucerne.

Corner, E.J.H. 1989: Ad Polyporaceas 5. - Nova Hedwigia 96:1-218.

David, A. \& Keller, J. 1984: Une nouvelle espèce de Skeletocutis (Polyporaceae) recoltée en Suisse. - Mycol. Helvetica 1: 157-167.

Domaniski, S., Orłos, H. \& Skirgiełło, A. 1973: Fungi, Polyporaceae II (pileatae), Mucronoporaceae II (pileatae) ... - 332 pp., 27 pls. Foreign Sci. Publ. Dept., Warsaw.

Dueñas, M. \& Tellería, T. 1988: Catálogo de los corticiáceos y poliporáceos, s.1. (Aphyllophorales, Basidiomycotina), de la micoflora Cántabro-Astur. - Ruizia 5:1-262.

Eriksson, J. \& Strid, A. 1969: Studies in the Aphyllophorales (Basidiomycetes) of northern Finland. - Rep. Kevo Subarctic Sta. 4:112-158.

Gilbertson, R.L. 1981: North American wood-rotting fungi that cause brown rots. - Mycotaxon 12:372-416.

Gilbertson, R.L., Burdsall Jr., H.H. \& Lindsey, J.P. 1974: Notes on wood-rotting Hymenomycetes in New Mexico. Southwestern Naturalist 19:347-360.

Gilbertson, R.L., Martin K. J. \& Lindsey, J.P. 1974: Annotated check list and host index for Arizona wood-rotting fungi. - Agric. Exp. Sta. Univ. Arizona Techn. Bull. 209:1-47.

Gilbertson, R.L. \& Ryvarden, L. 1986: North American polypores 1. Abortiporus to Lindtneria. -433 pp. Fungiflora, Oslo.

Gilbertson, R.L. \& Ryvarden, L. 1987: North American polypores 2. Megasporoporia to Wrightoporia. - Pp. 434-885. Fungiflora, Oslo.

Ginns, J.H. 1986: Compendium of plant disease and decay fungi in Canada 1960-1980. - Agric. Canada Publ. 1813:1-416.

Hallenberg, N. 1979: Wood-fungi (Polyporaceae, Ganodermataceae, Hymenochaetaceae, Cyphellaceae, Clavariaceae, Auriculariaceae, Tremellaceae, Dacrymycetaceae) in N. Iran 2. - Iranian J. Plant Path. 15:11-31.

Holmgren, P.K., Holmgren, N.H. \& Barnett, L.C. 1990: Index herbariorum 1. The herbaria of the world. 8th ed. Regnum Vegetabile 120: 1-693.

Järva, L. \& Parmasto, E. 1980: Eesti seente koondnimestik. Scripta Mycol. 7:1-331.

Jülich, W. 1984: Die Nichtblätterpilze, Gallertpilze und Bauchpilze (Aphyllophorales, Heterobasidiomycetes, Gasteromycetes). In: Gams, H. (ed.), Kleine Kryptogamenflora 2b(1), Basidiomyceten 1. - 626 pp. Gustav Fischer Verlag, Stuttgart \& New York.

Kaaro, J. 1992: Aarniometsăt sirpaleina. — Helsingin Sanomat 1.II.1992: D1.

Karsten, P.A. 1881: Symbolae ad mycologiam fennicam 7. Medd. Soc. F. Fl. Fennica 6:1-6.
Kaspar, R. 1979: Funalia trogii in der DDR. - Boletus 3:1-2.

Keller, J. 1986: Ultrastructure des parois sporiques de quelques Aphyllophorales. - Mycologia Helvetica 2:1-34.

Klán, J. \& Kotilová-Kubiðková, L. 1982: Macrofungi from the West Caucasus 1. Aphyllophoraceous fungi (Aphyllophorales, Basidiomycetes). — Ceská Mykol. 36:20-39.

Kotiranta, H. 1986: Skeletocutis lilacina and Tyromyces kmetii, two rare polypore species reported from Finland. Windahlia 16:85-88.

Kotiranta, H. 1989: Suomen uhanalaiset käävät. - Sienilehti 41:118-123.

Kotlaba, F. 1976: Contribution to the knowledge of the Turkish macromycetes. - Česká Mykol. 30:156-169.

Kotlaba, Z. 1984: Zeměpisné rozšíření a ekologie chorošů (Polyporales s.1.) v Československu. — 194 pp., 123 maps. Academia, Praha.

Kreisel, H. 1987: Pilzflora der Deutschen Demokratischen Republik. -281 pp. Gustav Fischer Verlag, Jena.

Kuthan, J. \& Kotlaba, F. 1981: Makromyzeten des Nationalparkes Ropotamo in Bulgarien. - Sborník Nár. Muz. Praze 37:77-136.

Kuthan, J. \& Kotlaba, F. 1988: Makromyzeten der bulgarischen Schwarzmeerküste und einiger Orte im landesinnern Bulgariens. - Sborník Nár. Muz. Praze B 44: 137-243.

Lowe, J.L. 1966: Polyporaceae of North America. The genus Poria. - State Univ. Coll. For. Syracuse Univ., Techn. Publ. 90:1-183.

Manninen, T. 1992: Aura Koivisto kohtasi salaperäisen haavanpökkelökäävän, sensaatiomainen kääpälöytö Porkkasalossa. - Ilta-Sanomat 20.VII.1992:10.

Murrill, W.A. 1905: The Polyporaceae of North America 11. A synopsis of the brown pileate species. - Bull. Torrey Bot. Club 32:353-371.

Niemelä, T. 1982a: Polypore survey of Finland 1. Introduction. - Karstenia 22:21-26.

Niemelä, T. 1982b: On Fennoscandian polypores 8. New genus Piloporia. - Karstenia 22:13-16.

Niemelä, T. 1985a: Mycoflora of Poste-de-la-Baleine, northern Québec. Polypores and the Hymenochaetales. - Naturaliste Canadien 112:445-472.

Niemelä, T. 1985b: On Fennoscandian polypores 9. Gelatoporia n.gen. and Tyromyces canadensis, plus notes on Skeletocutis and Antrodia. - Karstenia 25:21-40.

Niemelä, T. 1991: Suomen kääpien määritysopas. 6th ed. Helsingin Yliop. Kasvit. Lait. Monist. 125:1-105.

Niemelä, T. \& Kotiranta, H. 1991: Polypore survey of Finland 5. The genus Polyporus. - Karstenia 31:55-68.

Niemelä, T. \& Penttilä, R. 1992: Antrodia mellita (Basidiomycetes), a new large-pored polypore species with a continental distribution. - Ann. Bot. Fennici 29:57-67.

Niemelä, T. \& Ryvarden, L. 1983: Antrodiella citrinella: a new polypore species. - Karstenia 23:26-30.

Overholts, L.O. 1953: The Polyporaceae of the United States, Alaska, and Canada. - 466 pp. Univ. Michigan Press, Ann Arbor.

Parmasto, E. 1962: Novye vidy i raznovidnosti gribov. Tremellales i Aphyllophorales. - Bot. Mater. Otd. Spor. Rast. Bot. Inst. Akad. Nauk SSSR 15:125-137.

Parmasto, E. 1967: Trutovye griby severa Sovetskogo Soyuza. - Mikol. Fitopatol. 1:280-286.

Patouillard, N. 1900: Essai taxonomique sur les familles et les genres des Hyménomycètes. - 184 pp. Lons-le-Saunier.

Rassi, P. 1989: Aarnimăihiăisen, Ipidia sexguttata, suojelusuunnitelma (Conservation programme for Ipidia sexguttata). - 
13 pp. Helsinki (manuscript).

Rassi, P., Alanen, A., Kemppainen, E., Wickholm, M. \& Väisänen, R. 1986: Uhanalaisten eläinten ja kasvien suojelutoimikunnan mietinto 3. Suomen uhanalaiset kasvit. Komiteamietintö 1985(43). - 431 pp. Ympäristöministeriö, Helsinki.

Rassi, P., Kaipiainen, H., Mannerkoski, I. \& Ståhls, G. 1992: Uhanalaisten elainten ja kasvien seurantatoimikunnan mietintö. Komiteamietintő 1991(30). - 328 pp. Ympäristöministeriö, Helsinki.

Renvall, P. \& Niemelä, T. 1992: Basidiomycetes at the timberline in Lapland 3. Two new boreal polypores with intricate hyphal systems. - Karstenia 32:29-42.

Renvall, P., Renvall, T. \& Niemelä, T. 1991: Basidiomycetes at the timberline in Lapland 2. An annotated checklist of the polypores of northeastern Finland. - Karstenia 31:13-28.

Ryvarden, L. 1978: The Polyporaceae of North Europe 2. Inonotus to Tyromyces. - Pp. 215-507. Fungiflora, Oslo.

Ryvarden, L. 1986: Piloporia sajanensis (Parm.) Niemelä, a rare polypore in Fennoscandia. - Windahlia 16:97-98.

Ryvarden, L. 1991: Genera of polypores. Nomenclature and taxonomy. - Synopsis Fungorum 5:1-363.

Ryvarden, L. \& Gilbertson, R.L. 1984: Type studies in the Polyporaceae 15 , species described by L.O. Overholts, either alone or with J.L. Lowe. - Mycotaxon 19:137-144.

Ryvarden, L. \& Johansen, I. 1980: A preliminary polypore flora of East Africa. - $636 \mathrm{pp}$. Fungiflora, Oslo.

Schmid-Heckel, H. 1985: Zur Kenntnis der Pilze in den Nördlichen Kalkalpen. - Nationalpark Berchtesgaden Forschungsber. 8:1-201.

Shubin, V.I. \& Krutov, V.I. 1979: Griby Karelii i Murmanskoy oblasti. - 104 pp. Nauka, Leningrad.

Shvartsman, S.R. 1964: Geterobazidial'nye (Auriculariales, Tremellales, Dacryomycetales) i avtobazidial'nye (Exobasi- diales, Aphyllophorales) griby. In: Flora sporovyh rasteniy Kazahstana 4. - 716 pp. Akad. Nauk Kazahskoy SSR, Alma Ata.

Stepanova-Kartavenko, N.T. 1967: Afilloforovye griby Urala. - 296 pp. Akad. Nauk SSSR, Sverdlovsk.

Strid, A. 1979: Trametes trogii, blek borstticka, i Sverige. Svensk Bot. Tidskr. 72:305-308.

Strid, A. 1981: Incrustoporia sajanensis (Parm.) comb.nov. (Polyporaceae), a taiga species new to Fennoscandia. Wahlenbergia 7:135-139.

Thorn, G., Kotiranta, H. \& Niemelä, T. 1990: Polyporus pseudobetulinus comb. nov., new records in Europe and North America. - Mycologia 82:582-594.

Vampola, P. 1991: Antrodiella parasitica, nový druh chorošů. Antrodiella parasitica, a new species of polypores. - Česká Mykol. 45:10-14.

Winterhoff, W. (ed.) 1984 : Vorläufige Rote Liste der Grosspilze (Makromyzeten). In: Blab, J., Nowak, E., Trautmann, W. \& Sukopp, H.: Rote Liste der gefährdeten Tiere und Pflanzen in der Bundesrepublik Deutschland: 162-184. - Naturschutzaktuell.

Wojewoda, W. \& Lawrynowicz, M. 1986: Czerwona lista grzybów wielkoowocnikowych zagrożonych w Polsce. Red list of threatened macrofungi in Poland. In: Zarycki, K. \& Wojewoda, W. (eds.), Lista roślin wymierajæcych i zagrorzonych w Polsce. List of threatened plants in Poland 3: 47-82. - Panstwowe Wydawnictwo Naukowe, Warszawa.

Zerova, M.Y., Radzievs'kyy, G.G. \& Shevchenko, S.V. 1972: Bazydiomitsety 1, ekzobazydial'ni, afiloforal'ni, kantarelal'ni. In: Zerov, D.K. (ed.), Vyznachnyk grybiv Ukrainy 5. - 240 pp. Naukova Dumka, Kyiv.

Received on 5 March 1992 